\title{
Assessment of Indoor Benzene and Its Alkyl Derivatives Concentrations in Offices Belonging to University of Technology (Poland)
}

\author{
Barbara Kozielska *(D) and Dorota Kaleta
}

Citation: Kozielska, B.; Kaleta, D. Assessment of Indoor Benzene and Its Alkyl Derivatives Concentrations in Offices Belonging to University of Technology (Poland). Atmosphere 2021, 12, 51 .

https://doi.org/10.3390/

atmos12010051

Received: 18 November 2020 Accepted: 27 December 2020 Published: 31 December 2020

Publisher's Note: MDPI stays neutral with regard to jurisdictional clai$\mathrm{ms}$ in published maps and institutional affiliations.

Copyright: $(2020$ by the authors. Licensee MDPI, Basel, Switzerland This article is an open access article distributed under the terms and conditions of the Creative Commons Attribution (CC BY) license (https:// creativecommons.org/licenses/by/ $4.0 /)$.
Department of Air Protection, Silesian University of Technology, 22B Konarskiego St., 44-100 Gliwice, Poland; dorota.kaleta@polsl.pl

* Correspondence: barbara.kozielska@polsl.pl; Tel.: +48-32-237-15-30

\begin{abstract}
Indoor air contamination in office rooms is regarded as one of the most important issues in the protection of workers' health, because contaminants, even those occurring at low concentrations, can cause health problems for the office staff in view of the long exposure time. This paper presents the results of measurements of benzene and its alkyl derivatives (toluene, ethylbenzene, xylenes, styrene, and 1,3,5-trimethylbenzene)—known indicators of human exposure to volatile organic compounds (VOCs) in the air in newly renovated offices at University of Technology (Upper Silesia, Poland). Monthly samples of indoor and outdoor air were collected during the years 2018-2019 by passive methods and analyzed by thermal desorption-gas chromatography with flame ionization detector (TD-GC/FID). In the first month of measurements average concentrations of the sum of five VOCs under consideration was $127.7 \mu \mathrm{g} / \mathrm{m}^{3}$, then in subsequent months between $15.1 \mu \mathrm{g} / \mathrm{m}^{3}$ to $87.3 \mu \mathrm{g} / \mathrm{m}^{3}$. The average concentration of carcinogenic benzene was below $1.5 \mu \mathrm{g} / \mathrm{m}^{3}$. Toluene had the highest concentration among studied VOCs, accounting for as high as $60 \%$ and $84 \%$ of the total indoor and outdoor VOCs, respectively. High indoor-to-outdoor (I/O) ratios for ethylbenzene (7.1), $\mathrm{m}, \mathrm{p}$-xylene (9.8), and styrene (12.5) indicate the dominant role of indoor sources.
\end{abstract}

Keywords: VOC; BTEXS; I/O ratio; IAQ; diffusive samplers

\section{Introduction}

Indoor air quality (IAQ) can considerably affect human health and well-being. The issue of IAQ has attracted a great deal of attention of researchers, because people spend approximately $90 \%$ of their time indoors [1-3] - in homes, offices, schools, shops, and public spaces [4-7]. Furthermore, indoor air quality is essentially unmonitored and partly unregulated, even though pollutant concentrations are usually higher indoors than outdoors $[4,8,9]$. In the modern world, offices create work places for majority of population, where people spend over $12 \%$ of their life. It makes the indoor air quality extremely vital.

IAQ is strictly dependent on the occurrence of various biological, physical and chemical pollutants [1]. Among chemical organic compounds used to evaluate indoor air quality by $\mathrm{WHO}$, formaldehyde ( $\mathrm{HCHO})$, polycyclic aromatic hydrocarbons (PAHs), and volatile organic compounds (VOCs) [1] are pointed. VOCs are known for their adverse impact on human health even at trace levels [10]. Exposure to VOCs can have acute and chronic effects on health due to their chemical structure which results in carcinogenic, and non-carcinogenic effects $[10,11]$.

Among these VOCs, benzene, toluene, ethylobenzene, xylenes, and styrene (BTEXS) have been recognized as principal pollutants and considered to be indicators of human exposure to volatile organic compounds. They were ranked as the most frequently detected compounds in indoor [12] and they are in focus of indoor quality examinations $[4,5,8,9,13-16]$. 
Benzene has been reported as the predominant risk entity in indoor air, when compared with formaldehyde and naphthalene $[17,18]$. Benzene is classified by the International Agency for Research on Cancer (IARC) as carcinogenic to humans (Group 1), while ethylbenzene is classified as possibly carcinogenic to humans (Group 2B) $[19,20]$. Benzene and ethylbenzene exposure is perceived as the source of increased risk of leukemia and hematopoietic cancers [21,22]. Toluene and xylenes are not classifiable (Group 3), but they may produce reproductive adverse effects, especially when exposures are chronic at low to high concentrations [23].

Several sources of VOCs emission indoors have been identified. These include building materials and furnishing (carpeting, flexible and wooden flooring, wooden products, paint, plastics, installations, electronics, finishing equipment, etc.), as well as indoor activities related to these materials and the users themselves $[15,16,24]$. Further, frequent refurbishment in rooms leads to the elevated levels of VOCs (expecially BTEXS) posing adverse health effects to occupants and perceived as unpleasant odors, that lead to the users' discomfort [25] and even show significant associations with the occurrence of sick building syndrome [6].

It has been previous reported that indoor concentrations of BTEXS exhibit significant variability. For example, concentrations of carcinogenic benzene were reported as 1.3-2.3 $\mu \mathrm{g} / \mathrm{m}^{3}$ (Japan [26]), 2.29-2.33 $\mu \mathrm{g} / \mathrm{m}^{3}$ (Poland, Upper Silesia [9]), $7.08 \mu \mathrm{g} / \mathrm{m}^{3}$ (Egypt, Cairo [27]), 7.3-8.2 $\mu \mathrm{g} / \mathrm{m}^{3}$ (India, New Dehli [11]) $15.18 \mu \mathrm{g} / \mathrm{m}^{3}$ (Iran, Arabil [28]) in residential homes and 6.5-7.9 $\mu \mathrm{g} / \mathrm{m}^{3}$ in public spaces (Korea [29]). Other values include $12.0 \mu \mathrm{g} / \mathrm{m}^{3}$ in restaurants (Korea, Seoul, Taegu [30]), and 9.9-36.0 $\mu \mathrm{g} / \mathrm{m}^{3}$ in hotels (India, New Delhi [11]). The concentration of toluene is usually higher and can be as high as $316.8 \mu \mathrm{g} / \mathrm{m}^{3}$ in public spaces in summer (Korea [29]).

Park and Ikeda studies have shown that the initial high concentrations of VOCs in the new constructed houses decreases significantly, approaching to the level of mean values for the older homes after one year. The results of [31] suggest existence of a steady emissions of VOCs within the first initial months. From the other side Brown found that renovated dwellings or new furniture can create much higher indoor VOC concentrations, which could persist for even several weeks [32].

Despite numerous studies on VOC indoor levels, the literature on the quality of the indoor environment is still insufficient. Collecting more data on IAQ is important, especially on BTEXS compounds, which next to formaldehyde, are classified as air toxics [33]. This study aims to (1) deliver data on the concentration of indoor VOCs in the newly renovated offices and to compare it against outdoor levels to evaluate the impact of recent renovation emissions in those offices, (2) determine the variability in the chemical composition of the VOCs, (3) identify their potential sources, wherever possible. Collected information will be useful for controlling/eliminating indoor sources, as well as for minimizing influence from outdoor sources. In addition, it will be possible to improve the environmental conditions for office staff and visiting students.

\section{Materials and Methods}

\subsection{Sampling Sites}

The place of samplings of indoor air were located in six newly renovated office rooms in University of Technology (Upper Silesia, Poland) (Figure 1). The renovation was carried out between June 2018 and September 2018, and included replacing all doors and painting walls and ceilings. Each room was equipped with new furniture made of MDF board. In offices 4 and 5, parquet floors were scraped and painted with thermosetting varnish. New tiles were laid in the remaining offices. Each room has office equipment, such as computers, monitors, laser printers, photocopiers, etc. Additional information is provided in Table S1. 

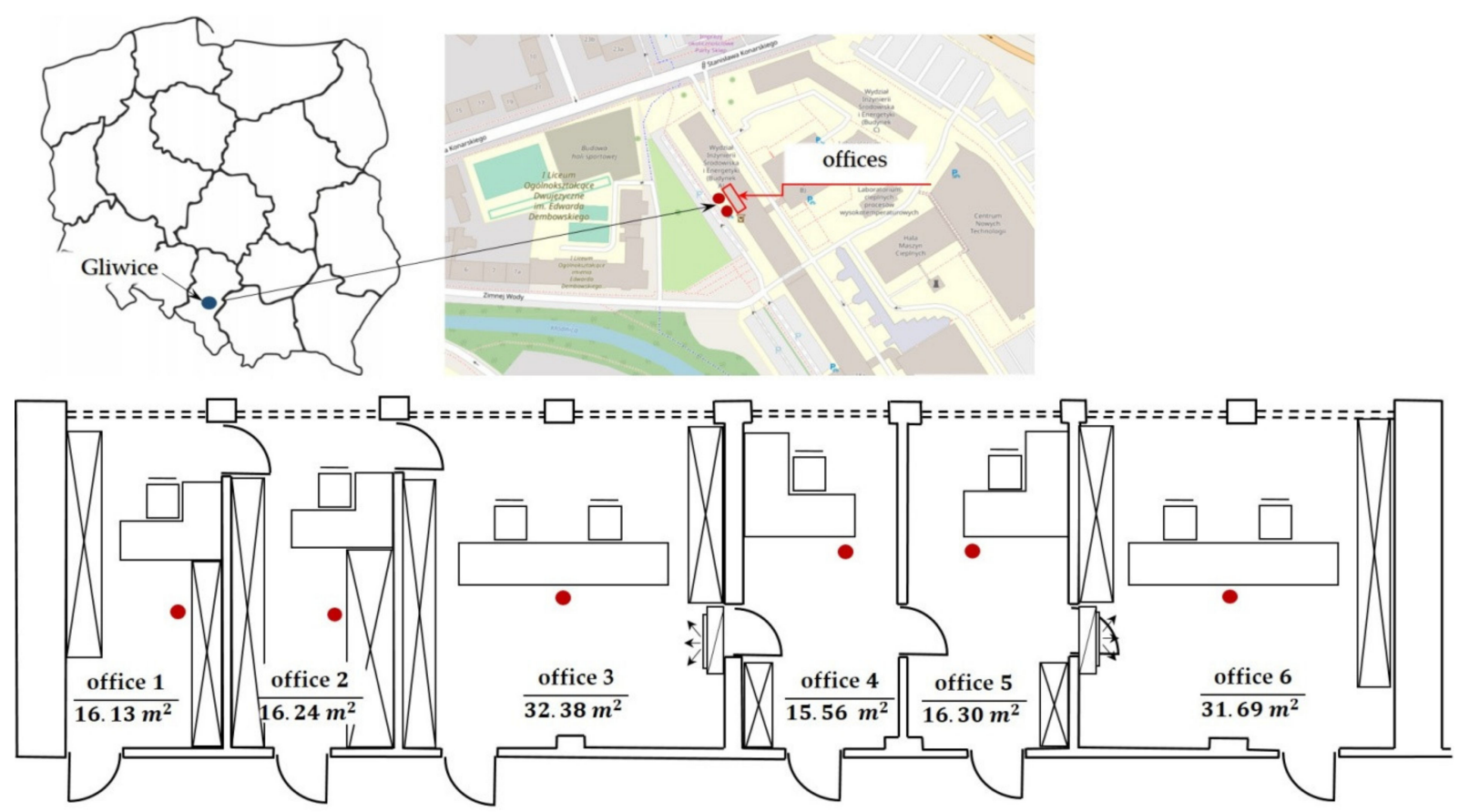

- sampling points

Figure 1. Location and plan of offices with outdoor (shown on the map) and indoor sampling points.

Benzene and its alkyl derivatives samples (including toluene, ethylbenzene, m,pxylene, o-xylene, styrene, and 1,3,5-trimethylbenzene-1,3,5-TMB) were collected immediately after the renovation, during the period from 1 October 2018 to 31 October 2019. The sampling points were set in the center of rooms at the height of an average adult's head when sitting at the desk (i.e., about $1.2 \mathrm{~m}$ above the floor) and away from the door and windows, thus avoiding disturbances resulting from air currents. Ambient air was collected at the same time outside the office windows.

All offices had air conditioning system. In some cases the windows were partially opened during measurements. The indoor air temperature was in the range of $21-22{ }^{\circ} \mathrm{C}$ and the outdoor average temperature was in the range $-4-20^{\circ} \mathrm{C}$. Every weekday morning the offices were cleaned (wet mopping with detergents analyzed as free from compounds of interest) before the employees started their work. The building in which the offices are located is insulated with Styrofoam. The university is smoke-free.

\subsection{Sampling and Analytical Methods}

The samples of benzene and its alkyl derivatives were collected for the entire year in one-month periods using an axial tube-type passive sampler. The passive method is based on Fick's first law, and the details are described in [34,35].

The sampling and BTEXS analysis method were adapted from published method by Jia and Fu [34]. Standard TD tubes packed with $200 \mathrm{mg}$ of Tenax GR, with the $1.5 \mathrm{~cm}$ air gap between the sampling end and sorbent surface, were applied. When a diffusion cap is fitted, the cross-sectional diffusion area is $0.196 \mathrm{~cm}^{2}$ (PerkinElmer Inc., Waltham, MA, USA). Diffusion coefficients for individual compounds needed for calculations were obtained from [36]. Prior sampling, tubes were conditioned at a temperature of $280^{\circ} \mathrm{C}$ for half an hour. Blank tubes did not show any target VOCs.

The exposure time of passive samplers was 30 days. When in use, the sampler had, from the sampling end, a diffusion cap, an air gap, a retaining gauze mesh, a sorbent bed, another retaining gauze and a spring. After the defined exposure time, the diffusion cap was removed and it was replaced with a storage cap. Passive samplers were then transferred to the analytical laboratory. 
Passive samplers, without storage caps, were loaded into the thermal desorber. The samples were desorbed and chromatographic analysis was performed. Detail and conditions of the TD-GC/FID analysis were presented in Table 1.

Table 1. Thermal desorption-gas chromatography with flame ionization detector (TD-GC/FID) conditions.

\begin{tabular}{|c|c|c|}
\hline Instrument & Parameter & Settings \\
\hline \multirow{11}{*}{$\begin{array}{l}\text { Thermal desorber } \\
\text { Turbo-Matrix } 100 \\
\text { (PerkinElmer, Inc., } \\
\text { Waltham, MA, USA) }\end{array}$} & Valve temperature & $200^{\circ} \mathrm{C}$ \\
\hline & Tube oven temperature & $280^{\circ} \mathrm{C}$ \\
\hline & Transfer line temperature & $250^{\circ} \mathrm{C}$ \\
\hline & Trap low temperature & $\left(-5^{\circ} \mathrm{C}\right)$ \\
\hline & Trap high temperature & $280^{\circ} \mathrm{C}$ \\
\hline & Pure time & $1 \mathrm{~min}$ \\
\hline & Desorb time & $3 \mathrm{~min}$ \\
\hline & Desorb flow & $25 \mathrm{~mL} / \mathrm{min}$ \\
\hline & Inlet split & $25 \mathrm{~mL} / \mathrm{min}$ \\
\hline & Outlet split & $8 \mathrm{~mL} / \mathrm{min}$ \\
\hline & Carrier $(\mathrm{He})$ pressure & $100 \mathrm{kPa}$ \\
\hline \multirow{6}{*}{$\begin{array}{c}\text { Gas chromatograph } \\
\text { Clarus } 500 \\
\text { (PerkinElmer, Inc., } \\
\text { Waltham, MA, USA) }\end{array}$} & RTX-5 (Restek) & $30 \mathrm{~m} \times 0.32 \mathrm{~mm} \times 3.00 \mu \mathrm{m}$ \\
\hline & capillary column & non-polar stationary phase \\
\hline & Flow of carrier gas $(\mathrm{He})$ & $2 \mathrm{~mL} / \mathrm{min}$ \\
\hline & Temperature program & $50{ }^{\circ} \mathrm{C}$ hold for $2 \mathrm{~min}$; \\
\hline & Iemperature program & $8^{\circ} \mathrm{C} / \mathrm{min}$ to $220^{\circ} \mathrm{C}$ \\
\hline & Total run time & $23 \mathrm{~min}$ \\
\hline \multirow{3}{*}{ Flame Ionization Detector } & Temperature & $260^{\circ} \mathrm{C}$ \\
\hline & Flow of hydrogen & $45 \mathrm{~mL} / \mathrm{min}$ \\
\hline & Flow of air & $450 \mathrm{~mL} / \mathrm{min}$ \\
\hline
\end{tabular}

The external standard calibration method was performed using a calibration mix containing 16 VOCs (containing benzene, toluene, ethylbenzene, $\mathrm{m}$ - and p-xylene, o-xylene, styrene, 1,3,5-trimethylbenzene) in the methanol solution in which the concentration of each VOCs was $2000 \mu \mathrm{g} / \mathrm{mL}$ (U-DWM-550 Aromatic Hydrocarbons Mixture ULTRA Scientific). Calibrations were obtained from standards injected on the sorbent tubes and analyzed like real samples. Five-point calibration curves were created for concentration range 20-400 $\mu \mathrm{g} / \mathrm{mL}$ (correlation coefficients: 0.97-0.99).

The lowest concentration of $0.2 \mathrm{ng} /$ sample was analyzed nine times to determine the limits of detection LODs. The LODs was calculated by multiplying standard deviation of nine determined masses by 3.14, the one-sided Student's $t$-value at $99 \%$ confidence corresponding to nine spikes analyzed.

Based on the 30-day samplings the LOD has been calculated (in $\mathrm{ng} / \mathrm{m}^{3}$ ). The sample limit of quantification (LOQ) can be derived from LOD as the LOQ is defined as three times the LOD concentration.

The limits of detection (LODs) ranged from $0.02 \mathrm{ng}$ for $\mathrm{p}, \mathrm{m}$-xylene to $0.04 \mathrm{ng}$ for benzene. Based on the 30-day sampling the LODs was $0.66 \mathrm{ng} / \mathrm{m}^{3}$ to $1.32 \mathrm{ng} / \mathrm{m}^{3}$ and limit of quantification (LOQ) ranged from 1.97 to $3.95 \mathrm{ng} / \mathrm{m}^{3}$ (Table S2).

\subsection{Statistical Analysis}

In order to present the general characteristics of the examined VOCs, the basic statistical parameters were calculated, i.e., the mean, standard deviation, median, 25th Percentile (Q1) and 75th Percentile (Q3), between which 50\% of the measured values of the studied variable is included.

In order to perform the statistical analysis, in the first step, it was checked, using the Shapiro-Wilk test, whether the examined variables came from a normally distributed population and whether the variances were homogeneous (Levene's test) [37-39]. When the calculated probability value ( $p$ ) for a given test was lower than the assumed significance 
level $\alpha=0.05$, then the null hypothesis about the normality of the distribution was rejected. This was equivalent to the statement that the distribution of the studied variable differs significantly from the normal distribution.

Due to the non-fulfillment of the criterion of the normal distribution (at the significance level $\alpha=0.05)$, non-parametric ANOVA was used utilizing the Kruskal-Wallis test for VOCs levels comparison between rooms $[40,41]$. Then, it was checked between which rooms there were significant differences in the distribution of VOCs concentrations by performing multiple comparison tests. The Mann-Whitney non-parametric test was performed to find homogeneous groups. When calculating the mean VOCs, the same letters denote the values for which there were no significant differences when the Mann-Whitney test was used at the significance level of 0.05 .

All statistical analysis were performed using the Statistica PL v. 13 package.

\section{Results and Discussion}

In order to meaningfully evaluate IAQ, the outdoors air quality has been evaluated first. The sampling was carried out on 30-day basis between October 2018 and October 2019.

The results have shown that the annual concentration of benzene in outdoor air was $0.90 \mu \mathrm{g} / \mathrm{m}^{3}$ on average $\left(0.25 \mu \mathrm{g} / \mathrm{m}^{3}\right.$ in August $2019-2.44 \mu \mathrm{g} / \mathrm{m}^{3}$ in January 2019) which is below the value of polish air quality standard $5 \mu \mathrm{g} / \mathrm{m}^{3}$ [42].

It was observed that in cold season, there was double the concentration of benzene in the air than in the warm season $\left(1.28 \mu \mathrm{g} / \mathrm{m}^{3}\right.$, Tables 2 and 3). Uchiyama et al. [26] noted also that the concentration of benzene was higher in the winter, than in the summer $\left(1.5 \mu \mathrm{g} / \mathrm{m}^{3}\right.$ and $1.0 \mu \mathrm{g} / \mathrm{m}^{3}$ respectively). Similar results have been obtained in the same time on the monitoring station in Katowice (Poland), where the concentration of benzene in winter was $2.40 \mu \mathrm{g} / \mathrm{m}^{3}$ and in the summer $1.5 \mu \mathrm{g} / \mathrm{m}^{3}$ [43]. These values are clearly higher than those presented in current study but the measurement point in Katowice, as a traffic monitoring station, is located near main road and undergo the high influence from vehicular traffic. Due to this fact, under the assumption that benzene is also derived from car exhausts (as it was reported by Srivastava and Devotta [44], and Jiang et. al. [45]) these results confirm the higher concentrations of benzene in winter compared to summer. For ethylbenzene, styrene, m,p-xylene, o-xylene, 1,3,5-TMB the concentrations were low and have not exceeded the value of $1.5 \mu \mathrm{g} / \mathrm{m}^{3}$. However, the average concentrations of toluene were the highest among other VOCs and ranged from $1.4 \mu \mathrm{g} / \mathrm{m}^{3}$ (in July 2019) to $125.3 \mu \mathrm{g} / \mathrm{m}^{3}$ (in December 2018). In the group of measured VOCs, the concentration of toluene exhibit about $84 \%$ in total.

In offices, the average concentration sum of the five investigated VOCs in all months under concern was $37.05 \mu \mathrm{g} / \mathrm{m}^{3}$. In the first month of measurements it was $127.67 \mu \mathrm{g} / \mathrm{m}^{3}$, then between $15.08 \mu \mathrm{g} / \mathrm{m}^{3}$ to $87.27 \mu \mathrm{g} / \mathrm{m}^{3}$ (Figure $\mathrm{S} 1$ ).

The remaining VOCs (except benzene) concentrations in all offices are characterized by some variability. Figure 2 and Table 3 provide descriptive statistics for VOCs concentrations measured in offices and outdoor in summer and winter seasons. Higher concentrations for VOCs were recorded during the summer season. The VOC with the highest median concentration observed in offices is toluene (warm season: $15.17 \mu \mathrm{g} / \mathrm{m}^{3}$ ) - it is also characterized by the highest concentration variation in the range $1.37-125.30 \mu \mathrm{g} / \mathrm{m}^{3}$ (Figure 2). The highest concentration of toluene among all alkyl derivatives of benzene compounds has been also confirmed by other authors [8,13,30,46-48]. 
Table 2. Mean and standard deviation (Mean $\pm \mathrm{SD}, \mu \mathrm{g} / \mathrm{m}^{3}$ ) for VOCs in offices and outdoors, cold (Oct-Mar) and warm (Apr-Sep) season.

\begin{tabular}{|c|c|c|c|c|c|c|c|}
\hline Room & Benzene & Toluene & Ethylbenzene & m,p-xylenes & o-xylenes & Styrene & 1,3,5-ТMB \\
\hline \multicolumn{8}{|c|}{ Cold Season (Oct-Mar) } \\
\hline office 1 & $1.05 \pm 0.57^{\mathrm{a}}$ & $14.43 \pm 20.68^{a}$ & $2.49 \pm 3.12^{a}$ & $3.18 \pm 4.78^{\mathrm{a}}$ & $1.34 \pm 1.08^{a}$ & $2.66 \pm 4.11^{\mathrm{a}}$ & $1.33 \pm 0.38^{a}$ \\
\hline office 2 & $1.08 \pm 0.65^{\mathrm{a}}$ & $14.21 \pm 23.83^{a}$ & $1.71 \pm 0.54 \mathrm{~b}$ & $2.25 \pm 0.87^{b}$ & $0.77 \pm 0.30^{\mathrm{a}}$ & $1.96 \pm 0.94^{b}$ & $1.18 \pm 0,34^{\mathrm{a}}$ \\
\hline office 3 & $1.17 \pm 0.76^{\mathrm{a}}$ & $20.67 \pm 38.69^{a}$ & $2.24 \pm 0.72^{a}$ & $3.38 \pm 1.11^{\mathrm{a}}$ & $0.77 \pm 0.24^{\mathrm{a}}$ & $3.15 \pm 0.98^{a}$ & $0.99 \pm 0.44^{\mathrm{a}}$ \\
\hline office 4 & $1.31 \pm 0.93^{a}$ & $28.09 \pm 30.63^{a}$ & $2.78 \pm 0.22^{\mathrm{a}}$ & $4.78 \pm 1.22^{\mathrm{a}}$ & $0.82 \pm 0.14^{\mathrm{a}}$ & $4.67 \pm 1.30^{\mathrm{a}}$ & $1.30 \pm 0.22^{a}$ \\
\hline office 5 & $1.05 \pm 0.61^{\mathrm{a}}$ & $21.99 \pm 28.02^{a}$ & $2.23 \pm 0.68^{a}$ & $3.91 \pm 1.63^{a}$ & $0.66 \pm 0.21^{\mathrm{a}}$ & $3.48 \pm 1.23^{\mathrm{a}}$ & $1.22 \pm 0.29^{a}$ \\
\hline office 6 & $1.13 \pm 0.68^{a}$ & $16.82 \pm 24.05^{\mathrm{a}}$ & $2.48 \pm 1.28^{\mathrm{a}}$ & $3.80 \pm 2.35^{\mathrm{a}}$ & $0.84 \pm 0.42^{a}$ & $3.40 \pm 1.45^{\mathrm{a}}$ & $1.24 \pm 0.32^{a}$ \\
\hline outdoor & $1.28 \pm 0.74^{\mathrm{a}}$ & $22.63 \pm 50.30^{\mathrm{a}}$ & $0.50 \pm 0.27^{c}$ & $0.46 \pm 0.10^{\mathrm{c}}$ & $0.39 \pm 0.29^{b}$ & $0.34 \pm 0.08^{c}$ & $1.31 \pm 1.01^{\mathrm{a}}$ \\
\hline \multicolumn{8}{|c|}{ Warm Season (Apr-Sep) } \\
\hline office 1 & $0.49 \pm 0.45^{\mathrm{a}}$ & $25.16 \pm 31.46^{\mathrm{a}}$ & $1.85 \pm 0.77^{a}$ & $1.84 \pm 0.93^{\mathrm{a}}$ & $1.91 \pm 2.38^{a}$ & $1.19 \pm 0.53^{\mathrm{a}}$ & $1.46 \pm 0.27^{a}$ \\
\hline office 2 & $0.55 \pm 0.67^{a}$ & $20.48 \pm 19.02^{a}$ & $2.21 \pm 0.82^{\mathrm{a}}$ & $2.34 \pm 1.80^{a}$ & $1.31 \pm 0.56^{\mathrm{a}}$ & $1.87 \pm 1.15^{\mathrm{a}}$ & $1.45 \pm 0.27^{\mathrm{a}}$ \\
\hline office 3 & $0.49 \pm 0.60^{a}$ & $21.40 \pm 32.75^{a}$ & $7.36 \pm 10.14^{b}$ & $6.08 \pm 3.38^{b}$ & $1.10 \pm 0.83^{a}$ & $4.78 \pm 3.23^{b}$ & $1.50 \pm 0.26^{\mathrm{a}}$ \\
\hline office 4 & $0.35 \pm 0.14^{a}$ & $17.76 \pm 6.68^{a}$ & $3.31 \pm 1.75^{c}$ & $4.16 \pm 2.60^{c}$ & $1.52 \pm 0.66^{\mathrm{a}}$ & $3.55 \pm 2.06^{c}$ & $1.79 \pm 0.36^{\mathrm{a}}$ \\
\hline office 5 & $0.42 \pm 0.31^{a}$ & $27.13 \pm 32.30^{a}$ & $4.64 \pm 3.86^{c}$ & $4.64 \pm 2.36^{c}$ & $1.37 \pm 0.50^{\mathrm{a}}$ & $6.52 \pm 6.06^{b}$ & $2.07 \pm 0.49^{a}$ \\
\hline office 6 & $0.44 \pm 0.34^{a}$ & $24.36 \pm 39.60^{a}$ & $4.30 \pm 3.72^{c}$ & $7.03 \pm 8.34^{b}$ & $1.40 \pm 1.07^{\mathrm{a}}$ & $6.17 \pm 5.99^{b}$ & $1.82 \pm 0.69^{a}$ \\
\hline outdoor & $0.57 \pm 0.63^{a}$ & $22.44 \pm 30.27^{a}$ & $0.53 \pm 0.42^{d}$ & $0.45 \pm 0.35^{\mathrm{d}}$ & $0.30 \pm 0.19^{b}$ & $0.31 \pm 0.20^{d}$ & $1.00 \pm 0.30^{a}$ \\
\hline
\end{tabular}

Identical letters (a-d) were used for means for which there is no significant differences in the Mann-Whitney test applied for $p>0.05$.

Table 3. Descriptive statistics of VOCs concentrations $\left(\mu \mathrm{g} / \mathrm{m}^{3}\right)$ in offices and outdoor (cold (Oct-Mar) and warm (Apr-Sep).

\begin{tabular}{|c|c|c|c|c|c|c|c|c|}
\hline \multirow{3}{*}{ VOC } & \multicolumn{8}{|c|}{ Cold Season (Oct-Mar) } \\
\hline & \multicolumn{4}{|c|}{ Indoor $(n=36)$} & \multicolumn{4}{|c|}{ Outdoor $(n=12)$} \\
\hline & Mean & SD & Min & Max & Mean & SD & Min & Max \\
\hline Benzene & 1.13 & 0.66 & 0.17 & 2.56 & 1.28 & 0.74 & 0.32 & 2.44 \\
\hline Toluene & 19.37 & 26.63 & 2.51 & 99.54 & 22.63 & 50.30 & 1.37 & 125.30 \\
\hline Ethylbenzene & 2.32 & 1.39 & 0.71 & 8.75 & 0.50 & 0.27 & 0.30 & 0.99 \\
\hline m,p-xylene & 3.55 & 2.35 & 0.69 & 12.91 & 0.46 & 0.10 & 0.31 & 0.61 \\
\hline o-xylene & 0.87 & 0.52 & 0.34 & 3.42 & 0.39 & 0.29 & 0.09 & 0.74 \\
\hline Styrene & 3.22 & 2.03 & 0.42 & 11.01 & 0.33 & 0.08 & 0.22 & 0.44 \\
\hline 1,3,5-TMB & 1.21 & 0.33 & 0.26 & 1.88 & 1.31 & 1.01 & 0.45 & 3.23 \\
\hline \multirow[t]{4}{*}{ Sum VOCs } & 32.05 & 30.41 & 8.02 & 116.31 & 26.90 & 50.47 & 3.50 & 129.77 \\
\hline & \multicolumn{8}{|c|}{ Warm Season (Apr-Sep) } \\
\hline & \multicolumn{4}{|c|}{ Indoor $(n=41)$} & \multicolumn{4}{|c|}{ Outdoor $(n=14)$} \\
\hline & Mean & SD & Min & Max & Mean & SD & Min & Max \\
\hline Benzene & 0.46 & 0.44 & 0.10 & 2.04 & 0.57 & 0.63 & 0.25 & 1.97 \\
\hline Toluene & 25.24 & 27.77 & 1.78 & 113.83 & 22.44 & 30.27 & 1.90 & 90.03 \\
\hline Ethylbenzene & 3.96 & 4.88 & 0.74 & 29.97 & 0.53 & 0.42 & 0.29 & 1.48 \\
\hline m,p-xylene & 4.24 & 4.25 & 0.81 & 25.67 & 0.45 & 0.35 & 0.21 & 1.23 \\
\hline o-xylene & 1.43 & 1.16 & 0.32 & 7.20 & 0.30 & 0.19 & 0.12 & 0.71 \\
\hline Styrene & 4.02 & 4.19 & 0.69 & 19.50 & 0.31 & 0.20 & 0.14 & 0.73 \\
\hline 1,3,5-TMB & 1.68 & 0.45 & 1.02 & 2.93 & 1.00 & 0.30 & 0.60 & 1.39 \\
\hline Sum VOCs & 38.13 & 36.65 & 6.85 & 177.92 & 25.33 & 32.24 & 4.06 & 97.54 \\
\hline
\end{tabular}



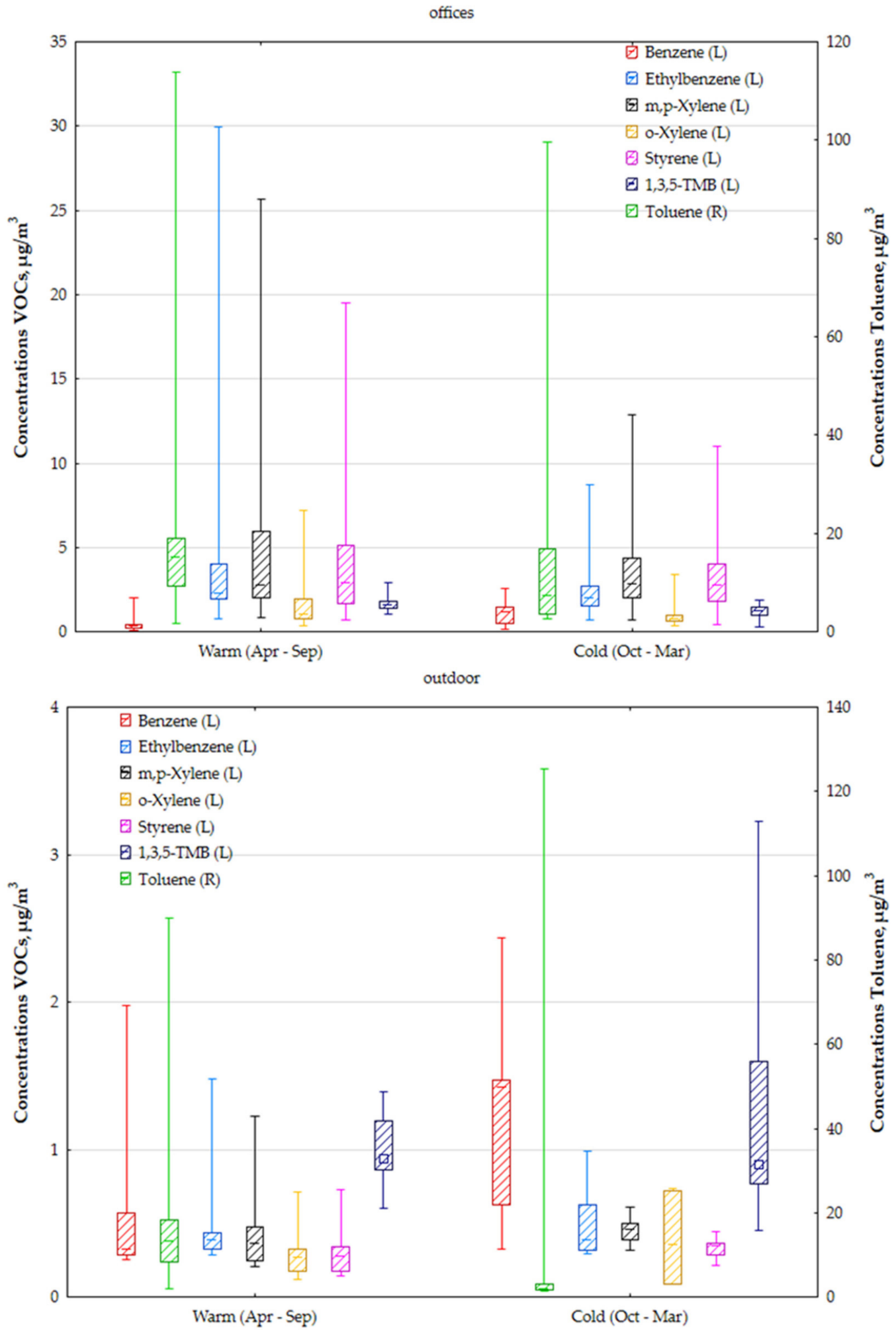

Figure 2. Box-whisker diagram for concentrations obtained in two measurement seasons, where: the central point- the median, the box (25th Percentile, 75th Percentile), whisker-the range (min-max).

For instance, the VOCs concentrations noted inside modern office buildings observed in works $[24,49]$ were of a similar altitude, except toluene-its concentration both in summer and winter $\left(25.2 \mu \mathrm{g} / \mathrm{m}^{3}\right.$ in the summer and $19.4 \mu \mathrm{g} / \mathrm{m}^{3}$ in the winter) were significantly higher than those found in [24] $\left(4.5 \mu \mathrm{g} / \mathrm{m}^{3}\right.$ and $3.5 \mu \mathrm{g} / \mathrm{m}^{3}$ respectively), with 
a maximum concentration of $113.8 \mu \mathrm{g} / \mathrm{m}^{3}$ and $99.5 \mu \mathrm{g} / \mathrm{m}^{3}$ in summer and winter sampling seasons (Table 3).

Average concentrations obtained during measurements of benzene- the most dangerous in the group of considered compounds, ranged from $1.05 \mu \mathrm{g} / \mathrm{m}^{3}$ (offices 1 and 5) to $1.31 \mu \mathrm{g} / \mathrm{m}^{3}$ (office 4) in cold and from $0.35 \mu \mathrm{g} / \mathrm{m}^{3}$ (office 4) to $0.55 \mu \mathrm{g} / \mathrm{m}^{3}$ (office 2) in warm (Table 2). These values are much lower than those reported in offices by other researchers-e.g., $87.1 \mu \mathrm{g} / \mathrm{m}^{3}$ in Singapore, $44.9 \mu \mathrm{g} / \mathrm{m}^{3}$ in Mumbai(India), $14.6 \mu \mathrm{g} / \mathrm{m}^{3}$ in Europe, $12.6 \mu \mathrm{g} / \mathrm{m}^{3}$ in Seoul (Korea) and $8.8 \mu \mathrm{g} / \mathrm{m}^{3}$ in Bangkok (Thailand) (Table 4). The concentrations of benzene in offices is also lower than in residential buildings and flats in the Upper Silesia (Poland) [9]. For ethylbenzene, styrene, xylenes and 1,3,5-TMB, the concentrations were relatively low and did not exceed $5 \mu \mathrm{g} / \mathrm{m}^{3}$ and $8 \mu \mathrm{g} / \mathrm{m}^{3}$ in cold and warm seasons, respectively. Concentrations of ethylbenzene, o-xylenes, styrene, and $1,3,5-\mathrm{TMB}$ stated in others various offices in the world, were below $20 \mu \mathrm{g} / \mathrm{m}^{3}$ (the exception is o-xylenes in Singapore-Table 4). In contrary, in the case of $\mathrm{m}, \mathrm{p}$-xylene higher concentrations have been reported-148 $\mu \mathrm{g} / \mathrm{m}^{3}$ in Singapore, $39 \mu \mathrm{g} / \mathrm{m}^{3}$ in Finland (Helsinki), and $23 \mu \mathrm{g} / \mathrm{m}^{3}$ in Korea (Seul) (Table 4).

Table 4. Occurrence of benzene (B), toluene (T), ethylbenzene (E), styrene (S), xylenes (Xe), 1,3,5-trimethylbenzene (1,3,5$\mathrm{TMB}$ ) — in indoor (I) and outdoor $(\mathrm{O}), \mu \mathrm{g} / \mathrm{m}^{3}$ other various offices in the world.

\begin{tabular}{|c|c|c|c|c|c|c|c|c|c|}
\hline Sampling Site & & B & $\mathbf{T}$ & $\mathrm{E}$ & m,p-xe & S & o-xe & 1,3,5-ТMB & Reference \\
\hline \multirow{2}{*}{ Korea, Seoul, Taegu } & $\mathrm{I}$ & 12.6 & 80.4 & 7.6 & 23.4 & 5.0 & 14.5 & 6.4 & \multirow[t]{2}{*}[30]{} \\
\hline & $\mathrm{O}$ & 8.18 & 50.25 & 5.51 & 16.25 & 4.00 & 9.01 & 2.90 & \\
\hline Hong Kong & I & 8.1 & 52.8 & 7.3 & 18.9 & 5.1 & 5.5 & 8.8 & [49] \\
\hline Singapore & I & 87.1 & 287.3 & & 143.0 & & 43.4 & & \multirow{2}{*}{ [13] } \\
\hline Europe & I & 14.6 & 35.1 & & 22.2 & & 10.2 & & \\
\hline Hungary & I & 2.7 & 2.2 & 0.5 & 1.2 & & 0.4 & & [47] \\
\hline \multirow{2}{*}{ India, Mumbai } & I & 44.92 & 0.82 & 0.06 & & & & 0.1 & [44] \\
\hline & $\mathrm{O}$ & 49.91 & & 0.20 & & & & 1.00 & \\
\hline \multirow{2}{*}{ Thailand, Bangkok } & $\mathrm{I}$ & 8.8 & 110 & 12.1 & 12.2 & 3.22 & 9.63 & & \multirow[t]{2}{*}{ [48] } \\
\hline & $\mathrm{O}$ & 2.98 & 43.65 & 5.50 & 5.33 & 1.05 & 4.21 & & \\
\hline \multirow{2}{*}{ Finland, Helsinki } & I & 3.9 & 32.3 & 16.1 & 38.8 & & 16.3 & 15.6 & \multirow[t]{2}{*}[50]{} \\
\hline & $\mathrm{O}$ & 1.7 & 5.6 & 1.0 & 3.1 & & & & \\
\hline \multirow{2}{*}{ Poland, Gliwice } & $\mathrm{I}$ & 1.2 & 10.8 & 0.6 & 0.5 & 0.3 & 1.2 & 6.7 & \multirow[t]{2}{*}{ [8] } \\
\hline & $\mathrm{O}$ & 0.63 & 8.18 & 0.17 & 0.23 & 0.12 & 0.05 & 0.31 & \\
\hline \multirow{2}{*}{ Poland, Upper Silesia } & I & 0.78 & 22.14 & 3.25 & 3.99 & 3.73 & 1.20 & 1.96 & \multirow{2}{*}{ This study } \\
\hline & $\mathrm{O}$ & 0.90 & 22.53 & 0.52 & 0.45 & 0.32 & 0.34 & 1.60 & \\
\hline
\end{tabular}

Average indoor/outdoor $(\mathrm{I} / \mathrm{O})$ ratios for benzene, calculated on the basis of presented results, were 0.83 and 0.88 (in warm and cold, respectively) (Figure 3). I/O ratio below 1 testifies that benzene present in outdoor air infiltrates into buildings [27,30]. It can be connected with a parking space for employees, located in front of the office building. In the case of average sum of selected VOCs measurements, I/O ratios were 1.4 in warm and 1.2 in cold. The highest I/O ratio was recorded for styrene, both in warm-11.3, and in cold-9.8 (Figure 3). In July 2019, it was 29.2. Also, high I/O ratio was noticed for ethylbenzene and $\mathrm{m}, \mathrm{p}$-xylene average 7.1 and 9.8, respectively. Such high values of I/O for styrene, ethylbenzene, and $\mathrm{m}, \mathrm{p}$-xylene suggest the existence of a variety of indoor emission sources. These sources include building materials, particularly paints and varnishes, and substances used by occupants such as odor eliminators and cosmetic products. Electronic devices create another source of indoor emission. Styrene and ethylbenzene can be also introduced into the air from the Styrofoam coating layer, commonly used as a building thermal insulation $[8,9]$. The outdoor sources also contribute to low $\mathrm{I} / \mathrm{O}$ and these include outdoor pollutants $[7,50]$. 


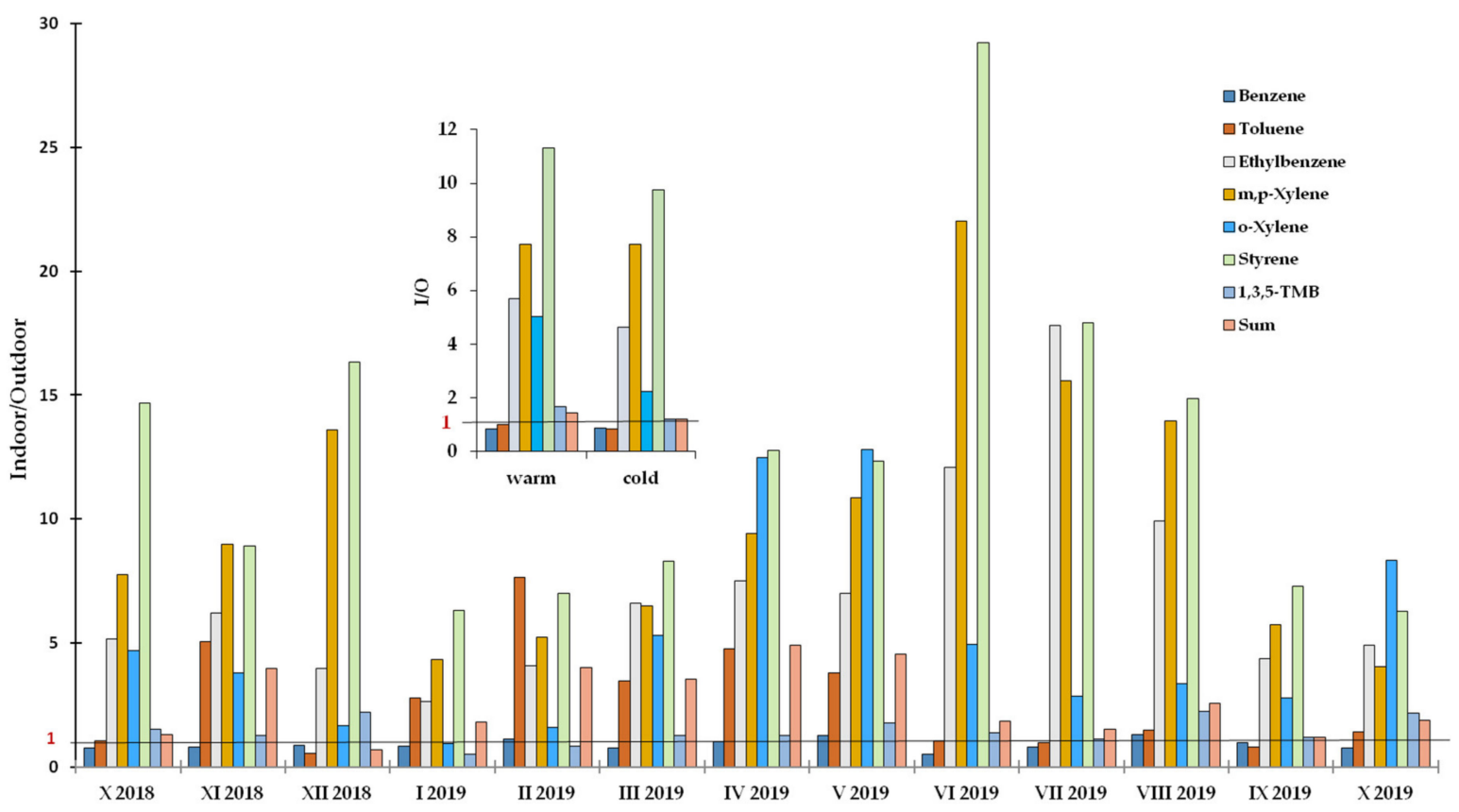

Figure 3. Indoor to outdoor ratios (I/O) of air pollutants.

Non-parametric variance analysis ANOVA was used to find the similarity between the different analyzed VOCs. The H statistic value for the Kruskal-Wallis test and the corresponding probability level were calculated (Table 5). On the basis of the results of the Kruskal-Wallis test at a significance level of 0.05 , it was found that for benzene, toluene and 1,3,5-TMB there are no statistically significant differences between the concentration levels recorded in different offices and outdoors, both during the cold and warm seasons. Additionally, based on the results of the Mann-Whitney test, homogeneous groups were indicated (Table 2). Identical letters (a-d) were used for means for which no significant differences were observed when the Mann-Whitney test was used with the calculated probability level $p>0.05$.

Table 5. Kruskal-Wallis test results for VOCs in the tested offices and outdoor.

\begin{tabular}{ccc}
\hline VOCs & $\mathbf{H}$ & $\mathbf{p}^{*}$ \\
\hline & Cold Season (Oct-Mar) & \\
\hline Benzene & 0.99 & 0.99 \\
Toluene & 9.84 & 0.13 \\
Ethylbenzene & 21.27 & 0.00 \\
m,p-Xylene & 25.72 & 0.00 \\
o-Xylene & 13.38 & 0.04 \\
Styrene & 25.81 & 0.00 \\
1,3,5-TMB & 3.92 & 0.69 \\
\hline & Warm Season (Apr-Sep) \\
Benzene & 1.001 & 0.98 \\
Toluene & 4.49 & 0.61 \\
Ethylbenzene & 23.16 & 0.00 \\
m,p-Xylene & 27.41 & 0.00 \\
o-Xylene & 18.10 & 0.01 \\
Styrene & 31.70 & 0.00 \\
1,3,5-TMB & 12.67 & 0.06 \\
\hline
\end{tabular}

H-statistical values for Kruskal-Wallis, $\mathrm{p}^{*}$-calculated level of significance. Cases where no significant differences were observed between the tested places are marked in red. 
The analyzed VOCs were divided into three groups (I, II, and III) depending on the recorded concentrations in the tested places (Table 6). The first group includes benzene, toluene, and 1,3,5-TMB, for which the average concentrations in all offices and outside are similar and there are no significant differences between them both in the warm and cold. The second group is o-xylenes with higher average concentrations indoors than outdoors in both warm and cold. The potential indoor sources for this group emissions could include dry process photocopiers, oil-based varnishes, carpets, plaster on walls, and use of adhesives like already reported by others $[13,24,51,52]$. The third group is ethylbenzene, $\mathrm{m}, \mathrm{p}$-xylene and styrene. In this case, there are significant differences both between the offices and the outdoors. A much greater differentiation was observed during the warm season, where these differences become to be significant in the case of most offices. During the cold, the observed differences become significant only in relation to office 2 and outdoor.

Table 6. Division of VOCs into groups.

\begin{tabular}{ccc}
\hline \multirow{2}{*}{ VOC, $\mu \mathrm{g} / \mathrm{m}^{3}$} & \multicolumn{2}{c}{ Group } \\
\cline { 2 - 3 } & Cold Season (Oct-Mar) & Warm Season (Apr-Sep) \\
\hline Benzene & I & I \\
Toluene & I & I \\
1,3,5-TMB & I & II \\
O-xylene & II & II \\
Ethylbenzene & III & III \\
m,p-xylene & III & III \\
Styrene & III & III \\
\hline
\end{tabular}

\section{Conclusions}

Research was conducted from October 2018 to October 2019 in newly renovated offices at the Upper Silesia University of Technology to assess the quality of indoor air. The investigation analyzed VOCs as benzene, toluene, ethylbenzene, styrene, m,p-xylene, o-xylene, and 1,3,5-TMB. In each of the six offices, all the mentioned VOCs were found. In the first month of measurements (immediately after the renovation), average concentration of the sum of the 7 investigated VOCs was about $130 \mu \mathrm{g} / \mathrm{m}^{3}$ and in the last month (almost a year after the renovation), $16 \mu \mathrm{g} / \mathrm{m}^{3}$. Indoor concentrations of nearly all pollutants were higher than outdoors. The only exception was benzene-in this case probably the influence of nearby parking car can be visible. It was also observed that the concentration of benzene was higher in cold than in warm seasons, although still below the air quality standard value of $5 \mu \mathrm{g} / \mathrm{m}^{3}$. The highest indoor-to-outdoor (I/O) ratio was for styrene, which belongs together with ethylbenzene and $\mathrm{m}, \mathrm{p}$-xylene, to the group with statistically significant concentration differences between the offices and the outdoors.

The findings presented in this study are relevant in view of air contamination and occupational safety. This study contributes to a better understanding of the contamination levels resulting from the recent renovation of offices and potential indoor and outdoor sources of VOCs. The high importance of the data on BTEXS arise from their classification as toxic compounds. In addition, most people spend about one-third of their day in offices that create a job environment for the majority of the modern population. Therefore, conducting such research seems important and should be developed in the future. In order to identify the main factors affecting the concentrations of indoor air pollutants, it is advisable to incorporate into such investigations additional parameters as temperature and humidity, buildings' structural characteristics, or occupants' activity patterns. It would be also interesting to conduct such studies not only after, but also before renovation and then to compare them. We intend to include this kind of comparison in our next study. 
Supplementary Materials: The following are available online at https://www.mdpi.com/2073-4 433/12/1/51/s1, Figure S1. Monthly concentrations of (a) benzene, ethylbenzene, xylens, styrene, 1,3,5-TMB, (b) toluene and sum VOCs in offices and Table S1. Characterization of offices; Table S2. The retention times, 30-day limits of detection (LODs) and 30-day limit of quantification (LOQ) of each BTEXS.

Author Contributions: Conceptualization, B.K.; Methodology, B.K. and D.K.; Formal analysis B.K.; Investigation and resources, B.K.; Data curation, D.K.; Writing-original draft preparation, B.K. and D.K.; Writing-review and editing, B.K.; Visualization, B.K. and D.K.; Supervision, B.K.; Project administration, B.K. All authors have read and agreed to the published version of the manuscript.

Funding: This work was supported by the Faculty of Power and Environmental Engineering, Silesian University of Technology (statutory research).

Ethical Review and Approval: Not applicable.

Informed Consent Statement: Not applicable.

Conflicts of Interest: The authors declare no conflict of interest.

\section{References}

1. WHO Regional Office for Europe. WHO Guidelines for Indoor Quality: Selected Pollutants; WHO Regional Office for Europe: Copenhagen, Denmark, 2010. Available online: http://www.euro.who.int/_data/assets/pdf_file/0009/128169/e94535.pdf (accessed on 8 September 2020).

2. Schweizer, C.; Edwards, R.; Bayer-Oglesby, L.; Gauderman, W.; Ilacqua, V.; Jantunen, M.; Lai, H.; Nieuwenhuijsen, M.; Kunzli, N. Indoor time-microenvironment-activity patterns in seven regions of Europe. J. Expo. Sci. Environ. Epidemiol. 2007, 17, 170-181. [CrossRef] [PubMed]

3. Antoniadou, P.; Papadopoulos, A.M. Occupants' thermal comfort: State of the art and the prospects of personalized assessment in office buildings. Energy Build. 2017, 153, 136-149. [CrossRef]

4. Goodman, N.B.; Steinemann, A.; Wheeler, A.J.; Paevere, P.J.; Cheng, M.; Brown, S.K. Volatile organic compounds within indoor environments in Australia. Build. Environ. 2017, 122, 116-125. [CrossRef]

5. Delgado-Saborit, J.M.; Aquilina, N.J.; Meddings, C.; Baker, S.; Harrison, R.M. Relationship of personal exposure to volatile organic compounds to home, work and fixed site outdoor concentrations. Sci. Total Environ. 2011, 409, 478-488. [CrossRef]

6. Takigawa, T.; Wang, B.L.; Sakano, N.; Wang, D.H.; Ogino, K.; Kishi, R. A longitudinal study of environmental risk factors for subjective symptoms associated with sick building syndrome in new dwellings. Sci. Total Environ. 2009, 407, 5223-5228. [CrossRef]

7. Spinazzè, A.; Campagnolo, D.; Cattaneo, A.; Cavallo, D.M.; Bartzis, J.G. Indoor gaseous air pollutants determinants in office buildings-The OFFICAIR project. Indoor Air 2020, 30, 76-87. [CrossRef]

8. Kozielska, B.; Bragoszewska, E.; Kaleta, D. Investigation of indoor air quality in offices and residential homes in an urban area of Poland. Air Qual. Atmos. Health 2020, 13, 131-141. [CrossRef]

9. Kozielska, B.; Mainka, A.; Żak, M.; Kaleta, D.; Mucha, W. Indoor air quality in residential buildings in Upper Silesia, Poland. Build. Environ. 2020, 177, 106914. [CrossRef]

10. Ramírez, N.; Cuadras, A.; Rovira, E.; Borrull, F.; Marcé, R.M. Chronic risk assessment of exposure to volatile organic compounds in the atmosphere near the largest Mediterranean industrial site. Environ. Int. 2012, 39, 200-209. [CrossRef]

11. Kumar, A.; Singh, B.P.; Punia, M.; Singh, D.; Kumar, K.; Jain, V.K. Determination of volatile organic compounds and associated health risk assessment in residential homes and hostels within an academic institute, New Delhi. Indoor Air 2014, 24, 474-483. [CrossRef]

12. Wolkoff, P.; Nielsen, G.D. Organic compounds in indoor air-Their relevance for perceived indoor air quality? Atmos. Environ. 2001, 35, 4407-4417. [CrossRef]

13. Zuraimi, M.S.; Roulet, C.-A.; Tham, K.W.; Sekhar, S.C.; David Cheong, K.W.; Wong, N.H.; Lee, K.H. A comparative study of VOCs in Singapore and European office buildings. Build. Environ. 2006, 41, 316-329. [CrossRef]

14. Śmiełowska, M.; Marć, M.; Zabiegała, B. Indoor air quality in public utility environments-A review. Environ. Sci. Pollut. Res. 2017, 24, 11166-11176. [CrossRef] [PubMed]

15. Bari, M.A.; Kindzierski, W.B.; Wheeler, A.J.; Héroux, M.-T.; Wallace, L.A. Source apportionment of indoor and outdoor volatile organic compounds at homes in Edmonton, Canada. Build. Environ. 2015, 90, 114-124. [CrossRef]

16. Marć, M.; Namieśnik, J.; Zabiegała, B. The miniaturised emission chamber system and home-made passive flux sampler studies of monoaromatic hydrocarbons emissions from selected commercially-available floor coverings. Build. Environ. 2017, 123, 1-13. [CrossRef]

17. Loh, M.M.; Levy, J.I.; Spengler, J.D.; Houseman, E.A.; Bennett, D.H. Ranking cancer risks of organic hazardous air pollutants in the United States. Environ. Health Perspect. 2007, 115, 1160-1168. [CrossRef]

18. Sarigiannis, D.A.; Karakitsios, S.P.; Gotti, A.; Liakos, I.L.; Katsoyiannis, A. Exposure to major volatile organic compounds and carbonyls in European indoor environments and associated health risk. Environ. Int. 2011, 37, 743-765. [CrossRef] 
19. IARC International Agency for Research on Cancer: Monographs on the Evaluation of Carcinogenic Risks to Humans. 2015. Available online: http:/ / monographs.iarc.fr/ENG/Classification/index.php (accessed on 10 December 2020).

20. Integrated Risk Information System (IRIS). Chemical Assessment Summary: Benzene. Available online: Cfpub.epa.gov/ncea/ iris/iris_documents/documents/subst/0276_summary.pdf (accessed on 10 December 2020).

21. Rumchev, K.; Brown, H.; Spickett, J. Volatile Organic Compounds: Do they present a risk to our health? Rev. Environ. Health 2007, 22, 39-55. [CrossRef]

22. Masekameni, M.D.; Moolla, R.; Gulumian, M.; Brouwer, D. Risk Assessment of Benzene, Toluene, Ethyl Benzene, and Xylene Concentrations from the Combustion of Coal in a Controlled Laboratory Environment. Int. J. Environ. Res. Public Health 2019, 16, 95. [CrossRef] [PubMed]

23. McKenzie, L.M.; Witter, R.Z.; Newman, L.S.; Adgate, J.L. Human health risk assessment of air emissions from development of unconventional natural gas resources. Sci. Total Environ. 2012, 424, 79-87. [CrossRef] [PubMed]

24. Campagnolo, D.; Saraga, D.E.; Cattaneo, A.; Cavallo, D.M.; Bartzis, J.G. VOCs and aldehydes source identification in European office buildings-The OFFICAIR study. Build. Environ. 2017, 115, 18-24. [CrossRef]

25. Bernstein, J.A.; Alexis, N.; Bacchus, H.; Bernstein, I.L.; Fritz, P.; Horner, E.; Li, N.; Mason, S.; Nel, A.; Oullette, J.; et al. The health effects of nonindustrial indoor air pollution. J. Allergy Clin. Immunol. 2008, 121, 585-591. [CrossRef] [PubMed]

26. Uchiyama, S.; Tomizawa, T.; Tokoro, A.; Aoki, M.; Hishiki, M.; Yamada, T.; Tanaka, R.; Sakamoto, H.; Yoshida, T.; Bekki, K.; et al. Gaseous chemical compounds in indoor and outdoor air of 602 houses throughout Japan in winter and summer. Environ. Res. 2015, 137, 364-372. [CrossRef]

27. Matysik, S.; Ramadan, A.B.; Schlink, U. Spatial and Temporal Variation of outdoor and indoor exposure of VOCs in Greater Cairo. Atmos. Pollut. Res. 2010, 1, 94-101. [CrossRef]

28. Hazrati, S.; Rostami, R.; Farjaminezhad, M.; Fazlzadeh, M. Preliminary assessment of BTEX concentrations in indoor air of residential buildings and atmospheric ambient air in Ardabil, Iran. Atmos. Environ. 2016, 132, 91-97. [CrossRef]

29. Seo, S.; Lim, S.; Lee, K.; Seo, Y.-K.; Baek, S.-O. Identification of volatile organic compounds in several indoor public places in Korea. Asian, J. Atmos. Environ. 2014, 8, 192-201. [CrossRef]

30. Baek, S.-O.; Kim, Y.-S.; Perry, R. Indoor air quality in homes, offices and restaurants in Korean urban areas-Indoor/outdoor relationships. Atmos. Environ. 1997, 31, 529-544. [CrossRef]

31. Park, J.S.; Ikeda, K. Variations of formaldehyde and VOC levels during 3 years in new and older homes. Indoor Air 2006, 16, 129-135. [CrossRef]

32. Brown, S.K. Volatile Organic Pollutants in New and Established Buildings in Melbourne, Australia. Indoor Air 2002, 12, 55-63. [CrossRef]

33. NEPM. National Environment Protection (Air Toxics) Measure; Environment Protection and Heritage Council: Canberra, ACT, Australia, 2004.

34. Jia, C.; Fu, X. Diffusive uptake rates of volatile organic compounds on standard ATD tubes for environmental and workplace applications. Environments 2017, 4, 87. [CrossRef]

35. Brown, R.H. Monitoring the ambient environment with diffusive samplers: Theory and practical considerations. J. Environ. Monit. 2000, 2, 1-9. [CrossRef] [PubMed]

36. U.S. Environmental Protection Agency (USEPA). EPA On-Line Tools for Site Assessment Calculation; USEPA: Washington, DC, USA, 2016.

37. Levene, H. Robust tests for equality of variances. In Contributions to Probability and Statistics: Essays in Honor of Harold Hotelling; Olkin, I., Ed.; Stanford University Press: Palo Alto, CA, USA, 1960; pp. 278-292.

38. Gastwirth, J.L.; Gel, Y.R.; Miao, W. The Impact of Levene's Test of Equality of Variances on Statistical Theory and Practice. Stat. Sci. 2009, 24, 343-360. [CrossRef]

39. Shapiro, S.S.; Wilk, M.B. An analysis of variance test for normality (complete samples). Biometrika 1965, 52, 591-611. [CrossRef]

40. Kruskal, W.H.; Wallis, W.A. Use of ranks in one-criterion variance analysis. J. Am. Stat. Assoc. 1952, 47, 583-621. [CrossRef]

41. Keselman, H.J.; Rogan, J.C.; Feir-Walsh, B.J. An evaluation of some non-parametric and parametric tests for location equality. Brit. J. Math. Stat. Psy. 1977, 30, 213-221. [CrossRef]

42. FAO. Regulation Concerning Levels of Some Substances Levels in the Air. J. Laws 2013, 1013. (In Polish)

43. Available online: http://powietrze.katowice.wios.gov.pl/dane-pomiarowe/pasywne/stacja/18/parametry/661/roczny/2019 (accessed on 30 October 2020).

44. Srivastava, A.; Devotta, S. Indoor air quality of public places in Mumbai, India in terms of volatile organic compounds. Environ. Monit. Assess. 2007, 133, 127-138. [CrossRef]

45. Jiang, Z.; Grosselin, B.; Daële, V.; Mellouki, A.; Mu, Y. Seasonal and diurnal variations of BTEX compounds in the semi-urban environment of Orleans, France. Sci. Total Environ. 2017, 574, 1659-1664. [CrossRef]

46. Chao, C.Y.; Chan, G.Y. Quantification of indoor VOCs in twenty mechanically ventilated buildings in Hong Kong. Atmos. Environ. 2001, 35, 5895-5913. [CrossRef]

47. Ongwandee, M.; Moonrinta, R.; Panyametheekul, S.; Tangbanluekal, C.; Morrison, G. Investigation of volatile organic compounds in office buildings in Bangkok, Thailand: Concentrations, sources, and occupant symptoms. Build. Environ. 2011, 46, 1512-1522. [CrossRef] 
48. Edwards, R.D.; Jurvelin, J.; Saarela, K.; Jantunen, M.J. VOC concentrations measured in personal samples and residential indoor, outdoor and workplace microenvironments in EXPOLIS-Helsinki, Finland. Atmos. Environ. 2001, 35, 4531-4543. [CrossRef]

49. Geiss, O.; Giannopoulos, G.; Tirendi, S.; Barrero-Moreno, J.; Larsen, B.R.; Kotzias, D. The AIRMEX study-VOC measurements in public buildings and schools/kindergartens in eleven European cities: Statistical analysis of the data. Atmos. Environ. 2001, 45, 3676-3684. [CrossRef]

50. Kik, K.; Bukowska, B.; Sicińska, P. Polystyrene nanoparticles: Sources, occurrence in the environment, distribution in tissues, accumulation and toxicity to various organisms. Environ. Pollut. 2020, 262, 114297. [CrossRef] [PubMed]

51. Leovic, K.W.; Sheldon, L.S.; Whitaker, D.A.; Hetes, R.G.; Calcagni, J.A.; Baskir, J.N. Measurement of indoor emissions from dry-process photocopy machines. J. Air Waste Manag. Assoc. 1996, 46, 821-829. [CrossRef]

52. Missia, D.A.; Demetriou, E.; Michael, N.; Tolis, E.I.; Bartzis, J.G. Indoor exposure from building materials: A field study. Atmos. Environ. 2010, 44, 4388-4395. [CrossRef] 